\title{
NCF2 wt Allele
}

National Cancer Institute

\section{Source}

National Cancer Institute. NCF2 wt Allele. NCI Thesaurus. Code C104564.

Human NCF2 wild-type allele is located in the vicinity of $1 \mathrm{q} 25$ and is approximately $35 \mathrm{~kb}$ in length. This allele, which encodes neutrophil cytosol factor 2 protein, is involved in the generation of superoxide in neutrophils. Mutations in this gene are associated with chronic granulomatous disease. 